\title{
Conformational Analysis, Substituent Effect and Structure activity Relationships of 16-Membered Macrodiolides
}

\author{
Radhia Mazri ${ }^{1}$, Salah Belaidi ${ }^{1, *}$, Aicha Kerassa $^{1}$, Touhami Lanez $^{2}$ \\ ${ }^{1}$ Group of Computational and Pharmaceutical Chemistry, LMCE Laboratory, Department of Chemistry, \\ Faculty of Sciences, University of Biskra, 07000, Biskra, Algeria \\ ${ }^{2}$ VTRS Laboratory, Faculty of Sciences and Technology, University of El-Oued, B.P. 789, \\ 39000, El-Oued, Algeria \\ *E-mail address: prof.belaidi@laposte.net
}

\begin{abstract}
Electronic structures, Conformational Analysis, effect of the substitution and structure activity Relationships for macrodiolides, have been studied by PM3 and ab initio methods. In the present work, the calculated values, namely net charges, bond lengths, MESP, dipole moments, electronaffinities, heats of formation, drug-likeness and QSAR properties, are reported and discussed in terms of the biological activity of macrodiolides.
\end{abstract}

Keywords: Macrodiolide; Antibiotic; Structure; Ab intio; PM3; Lipinski rule and QSAR Properties

\section{INTRODUCTION}

Macrocyclic motifs are commonly found in natural products and pharmaceutical molecules; and thus provide privileged scaffolds for medicinal chemistry programs in modern drug discovery [1,2].

Symmetric macrodiolides are present in many natural products with interesting biological activities [3-5], such as antibacterial, antifungal and cytotoxicity that offer both pharmacological and physicochemical advantages over acyclic molecules with regard to modulation of these problematic molecular targets. The physicochemical advantages of macrocycles result from their shape [6] and lower rotatable bond count [7].

The family of macrodiolide antibiotics consists of two classes of natural compounds displaying interesting biological properties [8]. The first class consists of 16-membered macrocycles and the second class is a 14-membered macrocycles [9]. QSAR has done much to enhance our understanding of fundamental processes and phenomena in medicinal chemistry and drug design [10-14].

Quantum chemistry methods play an important role in obtaining molecular geometries and predicting various properties [15]. To obtain highly accurate geometries and physical properties for molecules that are built from electronegative elements, expensive ab initio/HF electron correlation methods are required [16-18]. 
Drug-likeness is a qualitative concept used in drug design, which is estimated from the molecular structure before the substance is even synthesized and tested.

The calculation of drug-like property can give us better assumption of biological activity of certain molecule. The theoretical calculation and maintain of certain properties of a molecule can fulfill the parameters which are essential to show certain biological activity. Lipinski's rule of five (ROF) is a rule of thumb to evaluate drug-likeness or determine a chemical compound with a certain pharmacological or biological activity that would make it a likely orally active drug in humans [19].

The ROF is based on four properties of molecules, namely, molecular weight (MW), $\log \mathrm{P}$, number of hydrogen-bond donors (HBD) taken as equivalent to the number of - $\mathrm{OH}$ and $-\mathrm{NH}$ groups, and the number of hydrogen-bond acceptors (HBA) taken as equivalent to the number of oxygen and nitrogen atoms .

In this work, we have investigated the geometry, electronic structure and substituent effect for macrodiolide. Finally, we have studied some of QSAR proprieties and drug likeness proprieties of a series of macrodiolide derivatives reported in literature.

\section{MATERIAL AND METHODS}

Initial calculations were optimized using HyperChem 8.03 software [20]. The geometries of macrodiolide and its derivatives were first fully optimized by molecular mechanics, with $\mathrm{MM}+$ force-field $(\mathrm{rms}=0.001 \mathrm{Kcal} / \AA)$. Further, geometries were fully reoptimized by using PM3 method [21]. In the next step geometries were fully re-optimized by using $\mathrm{Ab}$ initio/HF (STO-3G) and ab initio/HF (6-31G).

The calculated results have been reported in the present work. The calculation of QSAR properties is performed by the module (QSAR Properties, version 8.0). QSAR Properties is a module that, together with HyperChem, allows several properties commonly used in QSAR studies to be calculated.

The calculations are empirical, so, generally, are fast. The calculated results have been reported in the present work.

\section{RESULTS AND DISCUSSION}

\section{1. Conformational analysis of 16-membered $\alpha, \beta$-unsaturated macrodiolides}

In this part, we propose to study the 16 -membered $\alpha, \beta$-unsaturated macrodiolides. Then, our objective is to search the favored conformations, on the basis of energy and geometric considerations with statistical calculations using Boltzmann distribution [14]. We have undertaken a conformational study of macrocycle 16 Figure 1 , symmetrical which we will design 16s $\left(n_{1}=n_{2}=4\right)$, dissymmetrical which we will design $16 \mathrm{~d}\left(n_{1}=3, n_{2}=5\right)$, which represent the core group for many antibiotics.

The most stable structures can be characterized by two structural characters: the two $\alpha$, $\beta$-unsaturated ester group, and the two saturated chains Figure 2. 


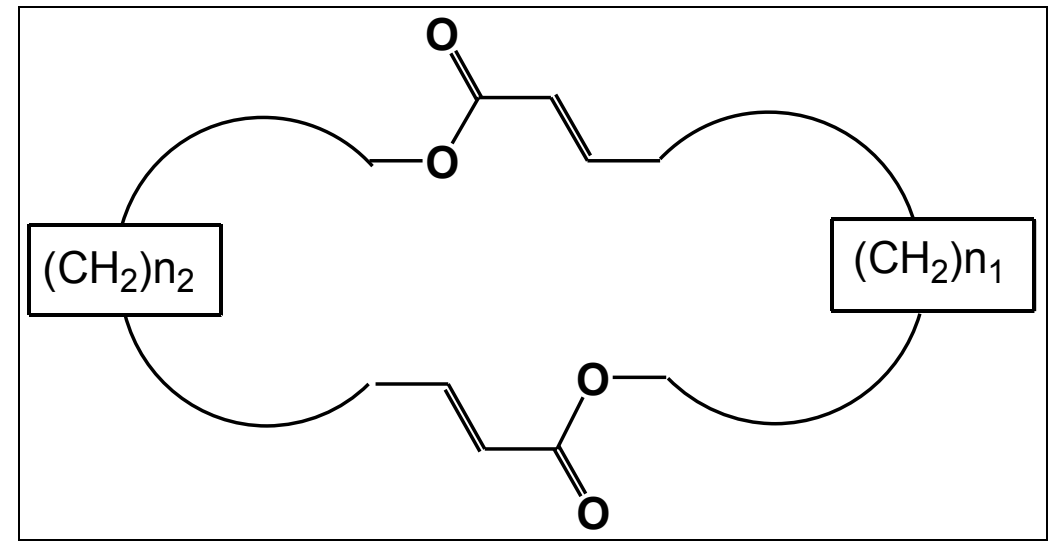

Figure 1. $\alpha, \beta$-unsaturated 16 macrodiolide.

Thus, we have obtained six types of conformations which are present in the majority of cases in $8 \mathrm{kcal} / \mathrm{mol}$ energy range above the global minimum.

The conformation types are classed from 1 to 6 two types $(1,3,5)$, the two planes of two conformational sites $\alpha, \beta$-unsaturated ester group were pseudo parallels; but for types (2, $4,6)$, the two planes of the two sites are pseudo antiparallel Figure 2.

In $2 \mathrm{kcal} / \mathrm{mol}$ difference, the macrocycle $16 \mathrm{~s}$ is characterized by the first conformer type 4 , which is the most favored with $31.3 \%$ rate followed by a type 1 with $20.5 \%$ and type 3 with $19.2 \%$.

Then, the macrocycle $16 \mathrm{~d}$ is presented preferably in the type T6 (47.8\%). The percentages of other conformation types are listed in Table 1.

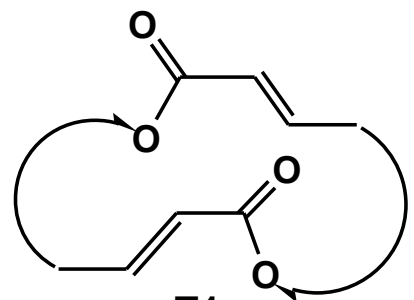

T1

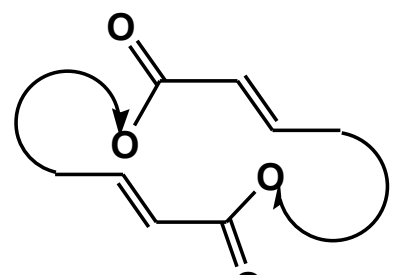

T2 0

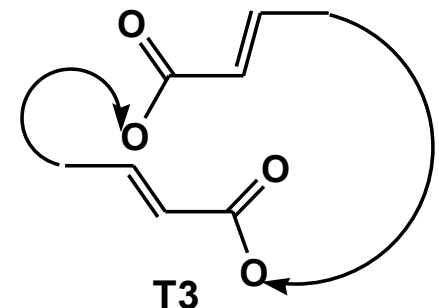

T3

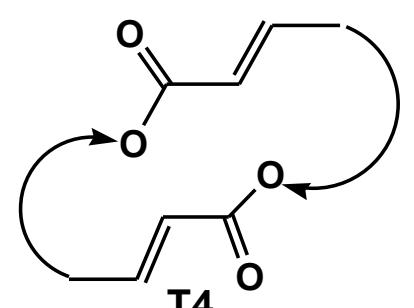

T4

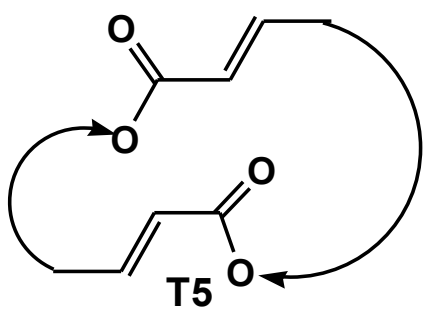

T5

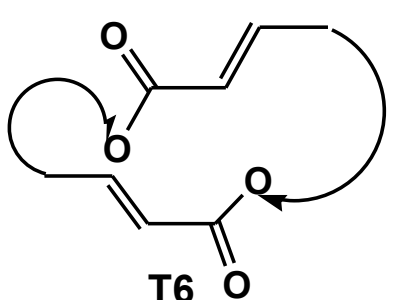

Figure 2. Main conformational types. 
Table 1. Energetic difference and Boltzmann population of different conformational types.

\begin{tabular}{|c|c|c|c|c|c|c|}
\hline \multirow{2}{*}{ Macrodiolide } & \multicolumn{3}{|c|}{$\begin{array}{c}16 \text { symmetric } \\
\left(\mathrm{n} 1=\mathrm{n}_{2}=3\right)\end{array}$} & \multicolumn{3}{c|}{$\begin{array}{c}16 \text { dissymmetric } \\
\left(\mathrm{n}_{1}=3, \mathrm{n}_{2}=5\right)\end{array}$} \\
\hline \multirow{3}{*}{ to $2 \mathrm{kcal} / \mathrm{mol}$} & Type & $\Delta \mathrm{E}$ & $\%$ & Type & $\Delta \mathrm{E}$ & $\%$ \\
\cline { 2 - 7 } & 4 & 00.00 & 31.3 & 6 & 00.00 & 47.8 \\
\cline { 2 - 8 } & 1 & 1.74 & 20.5 & & & \\
\cline { 2 - 8 } & 6 & 1.99 & 19.2 & & & \\
\cline { 2 - 8 } & 5 & 6.04 & 7.2 & 4 & 5.2 & 13.5 \\
\cline { 2 - 8 } $\mathrm{kcal} / \mathrm{mol}$ & 2 & 6.70 & 6.1 & 5 & 7.13 & 8.4 \\
\cline { 2 - 7 } & & & & 2 & 8.02 & 6.8 \\
\cline { 2 - 7 } & & & & 3 & 8.31 & 6.3 \\
\hline
\end{tabular}

$\Delta E$ : Energetic difference to the absolute minimum, \%: Boltzmann population.

\section{2. Geometric and Electronic Structure of Basic Structure of Symetric 16-membered Macrodiolide (Type 4)}

The efficiency of PM3 method may be scrutinized by comparison with the results obtained by more elaborate calculation such as ab initio/HF. Present results concerning from these results a good correlation can be seen between the ab initio, and PM3 for bond lengths, also the charge densities calculated by these methods are approximately similar. The Dihedral angles vary between 2.7 and 175.9 degrees, Table 2 .

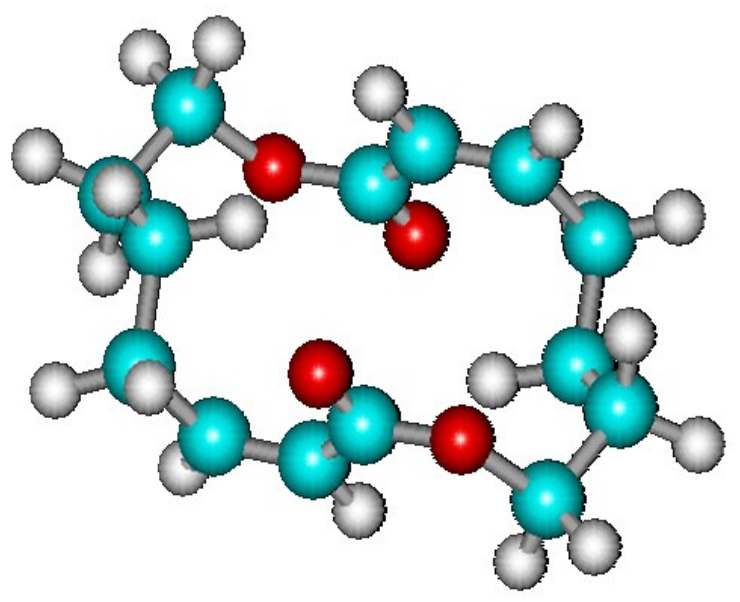

Figure 2. Conformation 3D of most favored conformer of 16 macrodiolide (type 4) (HyperChem). 
Table 2. Calculated values of bond lengths of macrodiolide T4.

\begin{tabular}{|c|c|c|c|c|}
\hline Bond length & MM & PM3 & $\begin{array}{c}\text { Ab initio/HF } \\
\text { (STO-3G) }\end{array}$ & $\begin{array}{c}\mathrm{Ab} \text { initio/HF } \\
(6-31 \mathrm{G})\end{array}$ \\
\hline $\mathrm{C} 1-\mathrm{C} 2$ & 1,358 & 1,478 & 1.514 & 1.475 \\
\hline $\mathrm{C} 2-\mathrm{C} 3$ & 1,345 & 1,336 & 1.317 & 1.331 \\
\hline $\mathrm{C} 3-\mathrm{C} 4$ & 1,511 & 1,485 & 1.524 & 1.503 \\
\hline $\mathrm{C} 4-\mathrm{C} 5$ & 1,541 & 1,525 & 1.553 & 1.542 \\
\hline $\mathrm{C} 5-\mathrm{C} 6$ & 1,541 & 1,523 & 1.547 & 1.536 \\
\hline $\mathrm{C} 6-\mathrm{C} 7$ & 1,537 & 1,527 & 1.549 & 1.521 \\
\hline $\mathrm{C} 7-\mathrm{O} 8$ & 1,409 & 1,417 & 1.442 & 1.454 \\
\hline $\mathrm{O} 8-\mathrm{C} 9$ & 1,349 & 1,385 & 1.304 & 1.361 \\
\hline C9-C10 & 1,358 & 1,478 & 1.513 & 1.475 \\
\hline $\mathrm{C} 10-\mathrm{C} 11$ & 1,345 & 1,336 & 1.317 & 1.331 \\
\hline $\mathrm{C} 11-\mathrm{C} 12$ & 1,511 & 1,485 & 1.524 & 1.503 \\
\hline $\mathrm{C} 12-\mathrm{C} 13$ & 1,541 & 1,525 & 1.553 & 1.542 \\
\hline C13-C14 & 1,541 & 1,523 & 1.547 & 1.536 \\
\hline C14-C15 & 1,537 & 1,527 & 1.549 & 1.521 \\
\hline C15-O16 & 1,409 & 1,417 & 1.442 & 1.454 \\
\hline $\mathrm{O} 16-\mathrm{C} 1$ & 1,349 & 1,385 & 1.404 & 1.361 \\
\hline C9-O17 & 1,207 & 1,214 & 1.219 & 1.212 \\
\hline C1-O18 & 1,207 & 1,214 & 1.219 & 1.212 \\
\hline
\end{tabular}

Table 3. Dihedral angles in degree.

\begin{tabular}{|c|c|c|}
\hline Dihedral angles & $\begin{array}{c}\text { Ab initio/HF } \\
(\mathrm{STO}-3 \mathrm{G})\end{array}$ & $\begin{array}{c}\mathrm{Ab} \text { initio/HF } \\
(6-31 \mathrm{G})\end{array}$ \\
\hline C1-C2-C3-C4 & 003.662 & 004.249 \\
\hline C2-C3-C4-C5 & 104.896 & 139.285 \\
\hline C3-C4-C5-C6 & 075.901 & 053.643 \\
\hline
\end{tabular}




\begin{tabular}{|c|c|c|}
\hline $\mathrm{C} 4-\mathrm{C} 5-\mathrm{C} 6-\mathrm{C} 7$ & 070.096 & 063.560 \\
\hline $\mathrm{C} 5-\mathrm{C} 6-\mathrm{C} 7-\mathrm{O} 8$ & 175.902 & 175.929 \\
\hline $\mathrm{C} 6-\mathrm{C} 7-\mathrm{O} 8-\mathrm{C} 9$ & 073.531 & 121.570 \\
\hline $\mathrm{C} 7-\mathrm{O} 8-\mathrm{C} 9-\mathrm{C} 10$ & 136.749 & 049.498 \\
\hline O8-C9-C10-C11 & 178.213 & 157.982 \\
\hline $\mathrm{C} 9-\mathrm{C} 10-\mathrm{C} 11-\mathrm{C} 12$ & 003.674 & 004.251 \\
\hline $\mathrm{C} 10-\mathrm{C} 11-\mathrm{C} 12-\mathrm{C} 13$ & 104.833 & 139.284 \\
\hline $\mathrm{C} 11-\mathrm{C} 12-\mathrm{C} 13-\mathrm{C} 14$ & 075.963 & 053.647 \\
\hline $\mathrm{C} 12-\mathrm{C} 13-\mathrm{C} 14-\mathrm{C} 15$ & 070.105 & 063.555 \\
\hline $\mathrm{C} 13-\mathrm{C} 14-\mathrm{C} 15-\mathrm{O} 16$ & 175.899 & 175.929 \\
\hline $\mathrm{C} 14-\mathrm{C} 15-\mathrm{O} 16-\mathrm{C} 1$ & 073.519 & 121.584 \\
\hline $\mathrm{C} 15-\mathrm{O} 16-\mathrm{C} 1-\mathrm{C} 2$ & 136.571 & 049.483 \\
\hline O16-C1-C2-C3 & 178.248 & 157.975 \\
\hline O18-C1-C2-C3 & 002.703 & 025.024 \\
\hline O18-C1-O16-C15 & 044.344 & 133.348 \\
\hline O17-C9-O8-C7 & 044.148 & 133.330 \\
\hline O17-C9-C10-C11 & 002.716 & 025.014 \\
\hline
\end{tabular}

Table 4. Mulliken charges of basic structure of macrodiolide T4.

\begin{tabular}{|c|c|c|}
\hline Macrodiolide & $\begin{array}{c}\mathrm{Ab} \text { initio/HF } \\
(\mathrm{STO}-3 \mathrm{G})\end{array}$ & $\begin{array}{c}\mathrm{Ab} \text { initio/HF } \\
(6-31 \mathrm{G})\end{array}$ \\
\hline $\mathrm{C} 1$ & 0.311 & 0.756 \\
\hline $\mathrm{C} 2$ & -0.100 & -0.293 \\
\hline $\mathrm{C} 3$ & -0.030 & -0.079 \\
\hline $\mathrm{C} 4$ & -0.115 & -0.368 \\
\hline $\mathrm{C} 5$ & -0.095 & -0.334 \\
\hline $\mathrm{C} 6$ & -0.113 & -0.300 \\
\hline $\mathrm{C} 7$ & 0.007 & 0.024 \\
\hline
\end{tabular}




\begin{tabular}{|l|l|l|}
\hline O8 & -0.263 & -0.742 \\
\hline C9 & 0.311 & 0.755 \\
\hline C10 & -0.100 & -0.293 \\
\hline C11 & -0.030 & -0.080 \\
\hline C12 & -0.115 & -0.368 \\
\hline C13 & -0.095 & -0.334 \\
\hline C14 & -0.113 & -0.024 \\
\hline C15 & 0.007 & 0.742 \\
\hline O16 & -0.263 & -0.756 \\
\hline O17 & -0.265 & -0.541 \\
\hline O18 & -0.265 & -0.454 \\
\hline
\end{tabular}

The Table 4 shows that the atoms C2, C3, C4, C5, C6, O8, C10, C11, C12, C13, C14, O16, O17 and $\mathrm{O} 18$ have negative Mulliken charges which leads to electrophilic substitution, whereas the atom $\mathrm{C} 1, \mathrm{C} 7, \mathrm{C} 9$ and $\mathrm{C} 15$ have positive Mulliken charge which lead to preferential site nucleophilic attack.

\section{3. The molecular electrostatic potential MESP of basic structure (T4)}

The molecular electrostatic potential surface MESP which is a plot of electrostatic potential mapped onto the iso-electron density surface simultaneously displays molecular shape, size and electrostatic potential values and has been plotted for both the molecules. Molecular electrostatic potential (MESP) mapping is very useful in the investigation of the molecular structure with its physiochemical property relationships [22-27]. In this study, the electrostatic potentials at the surface are presented by different colors Figure 4.

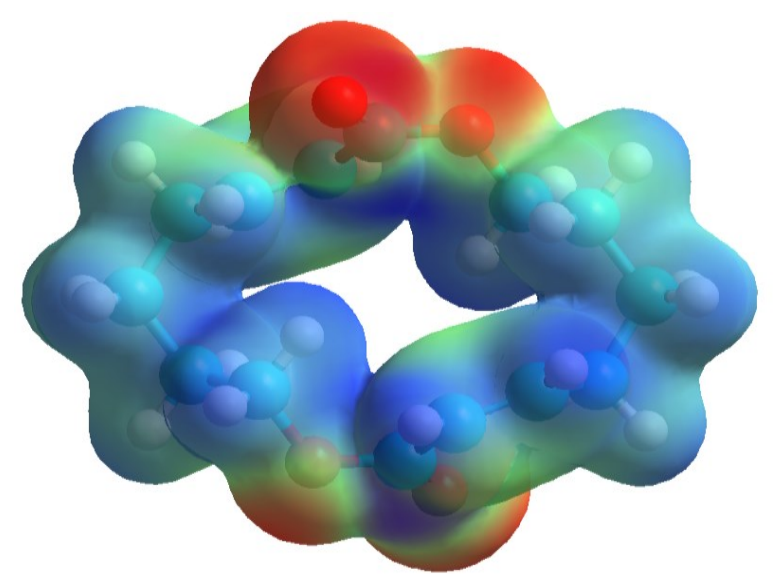

Figure 4. 3D MESP contour map for 16 macrodiolide molecule. 
Red color parts represent the regions of negative electrostatic potential while blue ones represent regions of positive electrostatic potential. Green color parts represent also regions of zero potential. A portion of the molecule that has a negative electrostatic potential is susceptible to electrophilic attack while the positive ones are related to nucleophilic reactivity.

\section{4. Substituent effects on the electronic structure in symmetric 16-membered macrodiolides}

$\mathrm{Ab}$ initio/HF method with (STO-3G) basis set was used to investigate the effects of a variety of substituents $\left(-\mathrm{CH}_{3}\right.$ and $\left.-\mathrm{Br}\right)$ on the electronic and structural properties of macrodiolide. In Table 5 and Table 6, HOMO and LUMO energies, energy gaps $\Delta \mathrm{E}$, heat of formation and dipole moments are reported for macrodiolide and its derivatives. The Mulliken charges of macrodiolide and its derivatives are listed in Table 7 and Table 8. The chemical structures of the studied macrodiolide and its derivatives are shown in Figure 5.

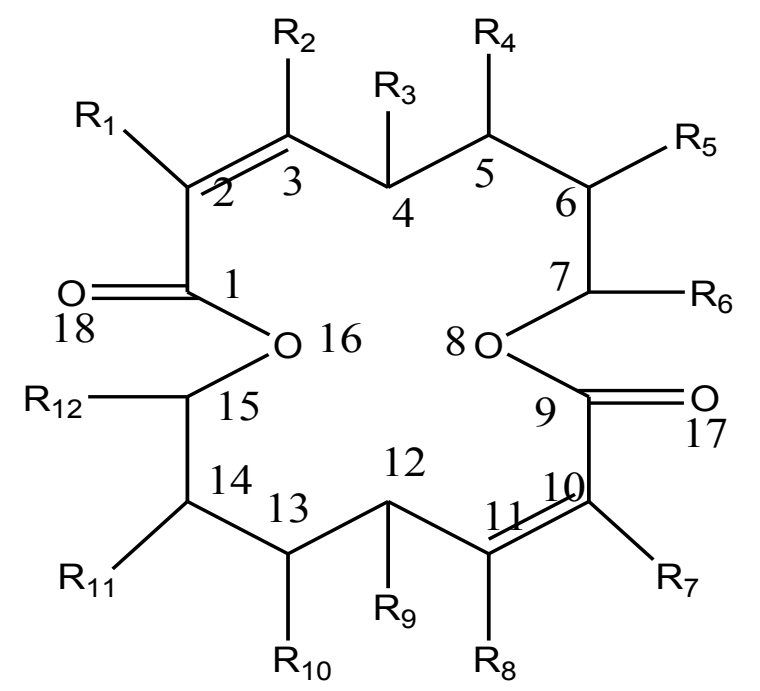

Series 1

1. $\mathrm{R} 1=\mathrm{R} 2=\mathrm{R} 3=\mathrm{R} 4=\mathrm{R} 5=\mathrm{R} 6=\mathrm{R} 7=\mathrm{R} 8=\mathrm{R} 9=\mathrm{R} 10=\mathrm{R} 11=\mathrm{R} 12=\mathrm{H}$

2. $\mathrm{R} 1=\mathrm{R} 7=\mathrm{CH} 3, \mathrm{R} 2=\mathrm{R} 3=\mathrm{R} 4=\mathrm{R} 5=\mathrm{R} 6=\mathrm{R} 8=\mathrm{R} 9=\mathrm{R} 10=11=\mathrm{R} 12=\mathrm{H}$

3. $\mathrm{R} 2=\mathrm{R} 8=\mathrm{CH} 3, \mathrm{R} 1=\mathrm{R} 3=\mathrm{R} 4=\mathrm{R} 5=\mathrm{R} 6=\mathrm{R} 7=\mathrm{R} 9=\mathrm{R} 10=\mathrm{R} 11=\mathrm{R} 12=\mathrm{H}$

4. $\mathrm{R} 3=\mathrm{R} 9=\mathrm{CH} 3, \mathrm{R} 1=\mathrm{R} 2=\mathrm{R} 4=\mathrm{R} 5=\mathrm{R} 6=\mathrm{R} 7=\mathrm{R} 8=\mathrm{R} 10=\mathrm{R} 11=\mathrm{R} 12=\mathrm{H}$

5. $\mathrm{R} 4=\mathrm{R} 10=\mathrm{CH} 3, \mathrm{R} 1=\mathrm{R} 2=\mathrm{R} 3=\mathrm{R} 5=\mathrm{R} 6=\mathrm{R} 7=\mathrm{R} 8=\mathrm{R} 9=\mathrm{R} 11=\mathrm{R} 12=\mathrm{H}$

6. $\mathrm{R} 11=\mathrm{R} 5=\mathrm{CH} 3, \mathrm{R} 1=\mathrm{R} 2=\mathrm{R} 3=\mathrm{R} 4=\mathrm{R} 6=\mathrm{R} 7=\mathrm{R} 8=\mathrm{R} 9=\mathrm{R} 10=\mathrm{R} 12=\mathrm{H}$

7. $\mathrm{R} 6=\mathrm{R} 12=\mathrm{CH} 3, \mathrm{R} 1=\mathrm{R} 2=\mathrm{R} 3=\mathrm{R} 4=\mathrm{R} 5=\mathrm{R} 7=\mathrm{R} 8=\mathrm{R} 9=\mathrm{R} 10=\mathrm{R} 11=\mathrm{H}$

Series 2

1. $\mathrm{R} 1=\mathrm{R} 2=\mathrm{R} 3=\mathrm{R} 4=\mathrm{R} 5=\mathrm{R} 6=\mathrm{R} 7=\mathrm{R} 8=\mathrm{R} 9=\mathrm{R} 10=\mathrm{R} 11=\mathrm{R} 12=\mathrm{H}$

2. $\mathrm{R} 1=\mathrm{R} 7=\mathrm{Br}, \mathrm{R} 2=\mathrm{R} 3=\mathrm{R} 4=\mathrm{R} 5=\mathrm{R} 6=\mathrm{R} 8=\mathrm{R} 9=\mathrm{R} 10=11=\mathrm{R} 12=\mathrm{H}$

3. $\mathrm{R} 2=\mathrm{R} 8=\mathrm{Br}, \mathrm{R} 1=\mathrm{R} 3=\mathrm{R} 4=\mathrm{R} 5=\mathrm{R} 6=\mathrm{R} 7=\mathrm{R} 9=\mathrm{R} 10=\mathrm{R} 11=\mathrm{R} 12=\mathrm{H}$

4. $\mathrm{R} 3=\mathrm{R} 9=\mathrm{Br}, \mathrm{R} 1=\mathrm{R} 2=\mathrm{R} 4=\mathrm{R} 5=\mathrm{R} 6=\mathrm{R} 7=\mathrm{R} 8=\mathrm{R} 10=\mathrm{R} 11=\mathrm{R} 12=\mathrm{H}$

5. $\mathrm{R} 4=\mathrm{R} 10=\mathrm{Br}, \mathrm{R} 1=\mathrm{R} 2=\mathrm{R} 3=\mathrm{R} 5=\mathrm{R} 6=\mathrm{R} 7=\mathrm{R} 8=\mathrm{R} 9=\mathrm{R} 11=\mathrm{R} 12=\mathrm{H}$

6. $\mathrm{R} 11=\mathrm{R} 5=\mathrm{Br}, \mathrm{R} 1=\mathrm{R} 2=\mathrm{R} 3=\mathrm{R} 4=\mathrm{R} 6=\mathrm{R} 7=\mathrm{R} 8=\mathrm{R} 9=\mathrm{R} 10=\mathrm{R} 12=\mathrm{H}$

7. $\mathrm{R} 6=\mathrm{R} 12=\mathrm{Br}, \mathrm{R} 1=\mathrm{R} 2=\mathrm{R} 3=\mathrm{R} 4=\mathrm{R} 5=\mathrm{R} 7=\mathrm{R} 8=\mathrm{R} 9=\mathrm{R} 10=\mathrm{R} 11=\mathrm{H}$

Figure 5. Scheme of macrodiolide systems. 
Table 5. Energies of macrodiolide and di-methyl substitute macrodiolides.

\begin{tabular}{ccccccc}
\hline Compound & System & $\begin{array}{c}\text { Heat of } \\
\text { formation } \\
\mathbf{( k c a l / m o l )}\end{array}$ & $\begin{array}{c}- \text { HOMO } \\
\mathbf{( e v )}\end{array}$ & $\begin{array}{c}\text { LUMO } \\
\mathbf{( e v )}\end{array}$ & $\begin{array}{c}\Delta \mathbf{E} \\
\mathbf{( e v})\end{array}$ & $\boldsymbol{\mu}(\mathbf{D})$ \\
\hline $\mathbf{1}$ & Macrodiolide & -145.9848 & 8.3558 & 6.3538 & 14.7096 & 0.0050 \\
$\mathbf{2}$ & 2,10-dimethyl macrodiolide & -160.20276 & 8.004333 & 6.545566 & 14.5498 & 0.0017 \\
$\mathbf{3}$ & 3,11-dimethyl macrodiolide & -165.15367 & 8.064455 & 6.459725 & 14.5499 & 0.0028 \\
$\mathbf{4}$ & 4,12-dimethyl macrodiolide & -163.40562 & 8.565975 & 6.412447 & 14.5242 & 0.0005 \\
$\mathbf{5}$ & 5,13-dimethyl macrodiolide & -163.43828 & 8.593216 & 6.410315 & 14.9784 & 0.1075 \\
$\mathbf{6}$ & 6,14-dimethyl macrodiolide & -163.073115 & 8.582869 & 6.421652 & 15.0035 & 0.0001 \\
$\mathbf{7}$ & 7,15-dimethyl macrodiolide & -158.02187 & 8.419232 & 6.268329 & 15.0045 & 0.0053 \\
\hline \multicolumn{7}{l}{ Note: Heat of formation by PM3 by HyperChem 8.06. HOMO, LUMO, $\mathrm{HE}$ and $\mu$ by Ab initio/HF }
\end{tabular}

(STO-3G).

Table 6. Energies of macrodiolide and di-bromine substitute macrodiolides.

\begin{tabular}{ccccccc}
\hline Compound & System & $\begin{array}{c}\text { Heat of } \\
\text { formation } \\
(\mathbf{k c a l} / \mathbf{m o l})\end{array}$ & $\begin{array}{c}- \text { HOMO } \\
(\mathbf{e v})\end{array}$ & $\begin{array}{c}\text { LUMO } \\
(\mathbf{e v})\end{array}$ & $\begin{array}{c}\Delta \mathbf{E} \\
(\mathbf{e v})\end{array}$ & $\boldsymbol{\mu}(\mathbf{D})$ \\
\hline $\mathbf{1}$ & Macrodiolide & -145.9848 & 8.3558 & 6.3538 & 14.7096 & 0.005 \\
$\mathbf{2}$ & 2,10-dibrominemacrodiolide & -130.5648 & 7.5892 & 5.9869 & 13.5761 & 0.0037 \\
$\mathbf{3}$ & 3,11-dibrominemacrodiolide & -135.1157 & 7.7678 & 6.0847 & 13.8525 & 0.0035 \\
$\mathbf{4}$ & 4,12-dibrominemacrodiolide & -163.4098 & 8.3616 & 5.7810 & 14.1426 & 0.0024 \\
$\mathbf{5}$ & 5,13-dibrominemacrodiolide & -141.396 & 8.3204 & 5.9517 & 14.2721 & 4.0813 \\
$\mathbf{6}$ & 6,14-dibrominemacrodiolide & -164.0099 & 8.3266 & 5.9657 & 14.2923 & 0004 \\
$\mathbf{7}$ & 7,15-dibrominemacrodiolide & -140.0745 & 8.3363 & 5.9935 & 14.3298 & 0.0003 \\
\hline
\end{tabular}

(STO-3G)

The heat of formation is decreased at each addition of di-methyl groups. Compound 3 (3,11-dimethylmacrodiolide) has the smallest value of the heat of formation. This compound (3) is more stable compared to other derivatives.

As has been seen by calculating the effect of a substituent donor increase the energy of the HOMO and that of the LUMO, while we see by calculating the effect of a substituent acceptor decrease the energy of the HOMO and that of the LUMO, Results in a stabilization of the HOMO and LUMO.

In the substituted di-methyl group category, the 4,12-dimethylmacrodiolide (compound 4) has smaller HOMO-LUMO energy gap (14.5242) Table 5 depicts the chemical reactivity of the compound; higher is the HOMO-LUMO energy gap, lesser is the flow of electrons to the higher energy state, making the molecule hard and less reactive. His maximum positive charge on 1stand 9rd position carbon (0.301) which leads to nucleophilic substitution Table 7. On the other hand in smaller HOMO-LUMO gap, there is easy flow of electrons to the higher energy state making it softer and more reactive (HSAB principle: hard and soft acids and bases). Hard bases have highest-occupied molecular orbitals (HOMO) of low energy, and hard acids have lowest-unoccupied molecular orbitals (LUMO) of high energy [28]. 
Table 7. Mulliken charges of macrodiolide and derivatives (series 1).

\begin{tabular}{|c|c|c|c|c|c|c|c|}
\hline Compound & 1 & 2 & 3 & 4 & 5 & 6 & 7 \\
\hline $\mathrm{C}-1$ & 0.311 & 0.307 & 0.311 & 0.301 & 0.301 & 0.301 & 0.305 \\
\hline $\mathrm{C}-2$ & -0.100 & -0.021 & -0.110 & -0.112 & -0.111 & -0.111 & -0.102 \\
\hline C-3 & -0.030 & -0.042 & 0.047 & -0.033 & -0.031 & -0.031 & -0.029 \\
\hline C-4 & -0.115 & -0.115 & -0.118 & -0.032 & -0.115 & -0.113 & -0.115 \\
\hline C-5 & -0.095 & -0.095 & -0.096 & -0.102 & -0.020 & -0.102 & -0.096 \\
\hline C-6 & -0.113 & -0.112 & -0.113 & -0.105 & -0.106 & -0.024 & -0.117 \\
\hline $\mathrm{C}-7$ & 0.007 & 0.007 & 0.005 & 0.012 & 0.012 & 0.009 & 0.089 \\
\hline O-8 & -0.263 & -0.265 & -0.263 & -0.262 & -0.262 & -0.263 & -0.270 \\
\hline C-9 & 0.311 & 0.307 & 0.311 & 0.301 & 0.301 & 0.301 & 0.305 \\
\hline $\mathrm{C}-10$ & -0.100 & -0.021 & -0.110 & -0.112 & -0.111 & -0.111 & -0.102 \\
\hline C-11 & -0.030 & -0.042 & 0.047 & -0.033 & -0.031 & -0.301 & -0.029 \\
\hline $\mathrm{C}-12$ & -0.115 & -0.115 & -0.118 & -0.032 & -0.114 & -0.113 & -0.115 \\
\hline C-13 & -0.095 & -0.095 & -0.096 & -0.102 & -0.019 & -0.102 & -0.096 \\
\hline C-14 & -0.113 & -0.112 & -0.113 & -0.105 & -0.107 & -0.024 & -0.117 \\
\hline C-15 & -0.007 & 0.007 & 0.005 & 0.012 & 0.011 & 0.009 & 0.089 \\
\hline O-16 & -0.263 & -0.265 & -0.263 & -0.262 & -0.262 & -0.263 & -0.270 \\
\hline O-17 & -0.265 & -0.266 & -0.271 & -0.241 & -0.240 & -0.241 & -0.256 \\
\hline C-18 & $\longrightarrow$ & -0.179 & -0.187 & -0.176 & -0.182 & -0.181 & -0.203 \\
\hline O-19 & -0.265 & -0.266 & -0.271 & -0.241 & -0.240 & -0.241 & -0.256 \\
\hline C-20 & 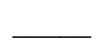 & -0.179 & -0.187 & -0.176 & -0.181 & -0.181 & -0.203 \\
\hline
\end{tabular}

Table 8. Mulliken charges of macrodiolide and derivatives (series 2).

\begin{tabular}{cccccccc}
\hline Compound & 1 & 2 & 3 & 4 & 5 & 6 & 7 \\
\hline C-1 & 0.311 & 0.318 & 0.303 & 0.313 & 0.311 & 0.301 & 0.308 \\
C-2 & -0.100 & -0.085 & -0.108 & -0.092 & -0.096 & -0.109 & -0.100 \\
C-3 & -0.030 & -0.031 & -0.010 & -0.032 & -0.030 & -0.032 & -0.027 \\
C-4 & -0.115 & -0.113 & -0.117 & -0.080 & -0.113 & -0.115 & -0.116 \\
C-5 & -0.095 & -0.095 & -0.099 & -0.097 & -0.062 & -0.101 & -0.098 \\
C-6 & -0.113 & -0.112 & -0.107 & -0.113 & -0.106 & -0.072 & -0.103 \\
C-7 & 0.007 & 0.011 & 0.011 & 0.009 & 0.011 & 0.011 & 0.041 \\
O-8 & -0.263 & -0.257 & -0.259 & -0.259 & -0.261 & -0.257 & -0.250 \\
C-9 & 0.311 & 0.318 & 0.303 & 0.313 & 0.314 & 0.301 & 0.308 \\
C-10 & -0.100 & -0.085 & -0.108 & -0.092 & -0.096 & -0.109 & -0.100 \\
C-11 & -0.030 & -0.031 & -0.010 & -0.032 & -0.032 & -0.302 & -0.027
\end{tabular}




\begin{tabular}{lllllllll} 
C-12 & -0.115 & -0.113 & -0.117 & -0.080 & -0.118 & -0.115 & -0.116 \\
C-13 & -0.095 & -0.095 & -0.099 & -0.097 & -0.062 & -0.101 & -0.098 \\
C-14 & -0.113 & -0.112 & -0.107 & -0.113 & -0.113 & -0.072 & -0.103 \\
C-15 & -0.007 & 0.011 & 0.011 & 0.009 & 0.006 & 0.011 & 0.041 \\
O-16 & -0.263 & -0.257 & -0.259 & -0.259 & -0.252 & -0.257 & -0.250 \\
O-17 & -0.265 & -0.256 & -0.246 & -0.263 & -0.242 & -0.233 & -0.264 \\
Br-18 & & 0.008 & 0.004 & -0.052 & -0.058 & -0.040 & -0.056 \\
O-19 & -0.265 & -0.256 & -0.246 & -0.263 & -0.288 & -0.233 & -0.264 \\
Br-20 & & 0.008 & 0.004 & -0.052 & -0.058 & -0.040 & -0.056 \\
\hline
\end{tabular}

The heat of formation is increased at each addition of di-bromine groups except for compound 4 and compound 6 heat of formation is decreased.

Compound 6 (6,14-dibrominemacrodiolide) has the smallest value of the heat of formation. This compound (6) is more stable compared to other derivatives.

As has been seen by calculating the effect of a substituent donor increase the energy of the HOMO and that of the LUMO.

In the substituted di-bromine group category, the 2,10-dibrominemacrodiolide (compound 2) has smaller HOMO-LUMO energy gap (13.5761) Table 6 depicts the chemical reactivity of the compound; higher is the HOMO-LUMO energy gap, lesser is the flow of electrons to the higher energy state, making the molecule hard and less reactive. His maximum positive charge on 1 st and 9 rd position carbon $(0.318)$ which leads to nucleophilic substitution Table 8 .

\section{5. Study of Structure - activity Relationships for 16-membered Macrodiolides}

We have studied seven physical and chemical proprieties of a series of eleven Macrodiolides derivatives Figure 6 using HyperChem 8.03 software. For example, Figure 7 shows the favored conformation in $3 \mathrm{D}$ of the Efomycine. We will continue this work in the future by a quantitative calculation.

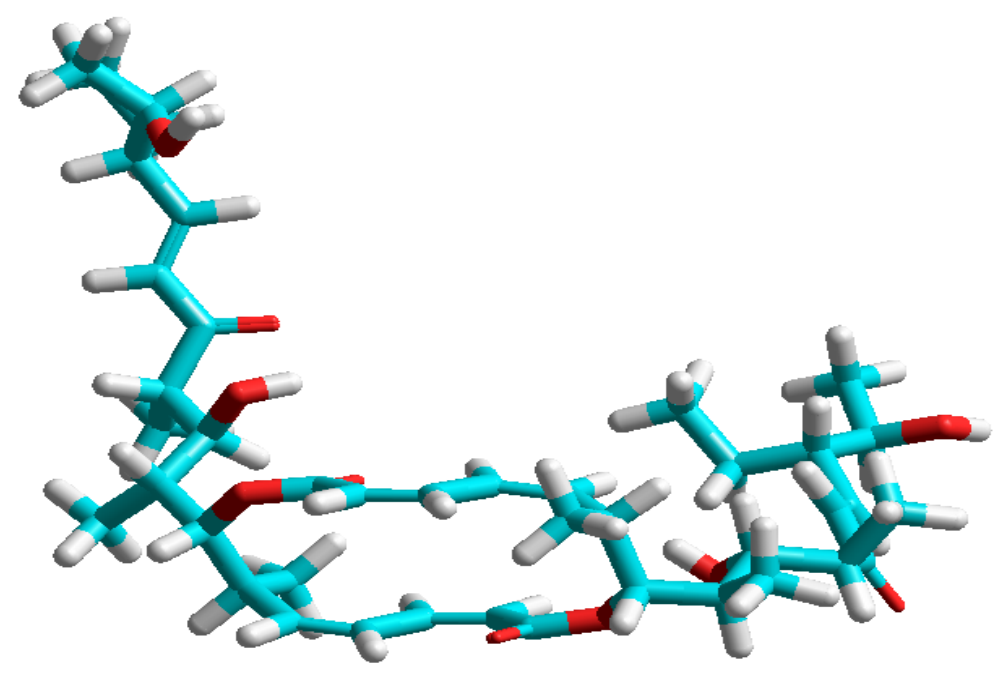

Figure. 7. 3D Conformation of Efomycine (HyperChem 8.03). 


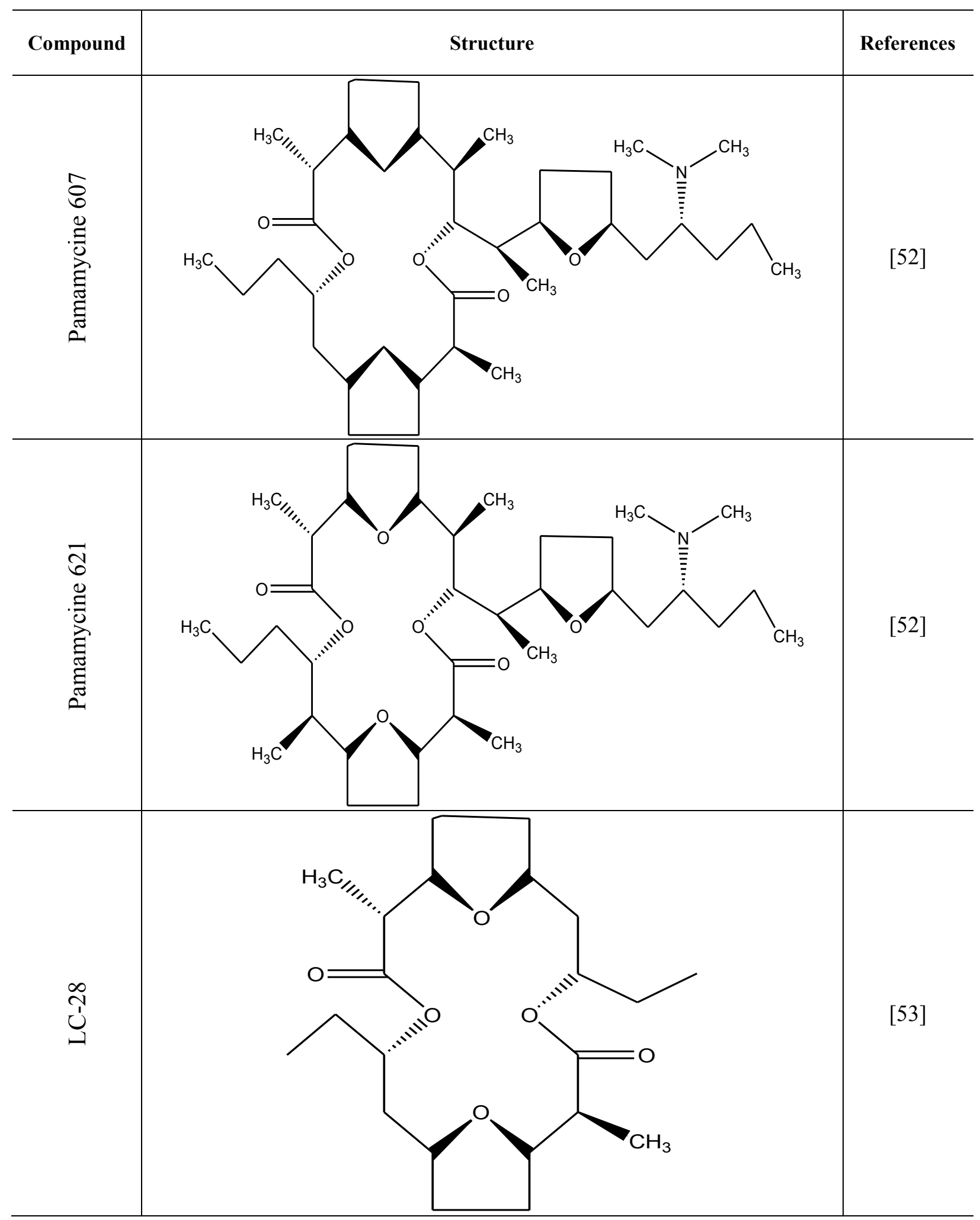




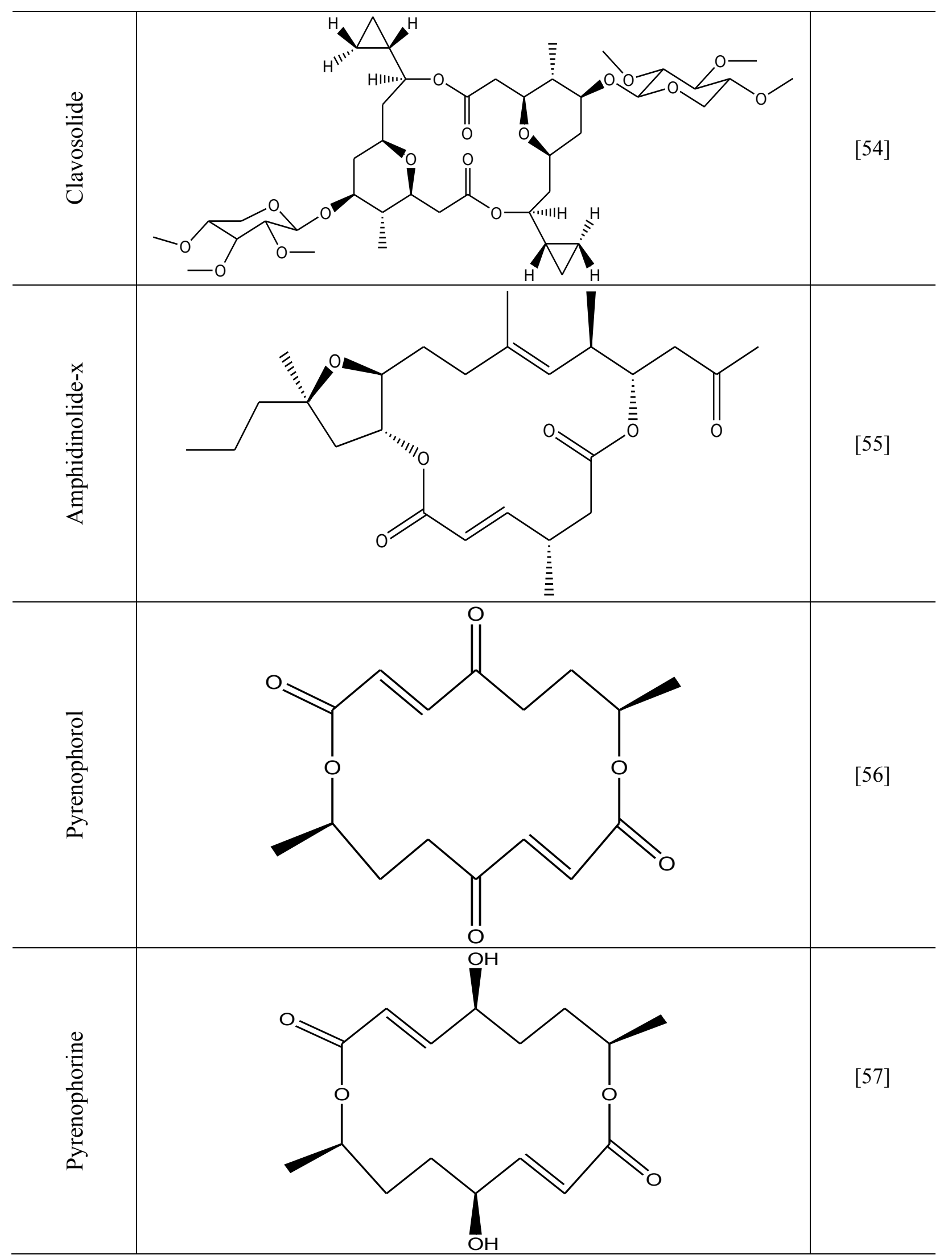




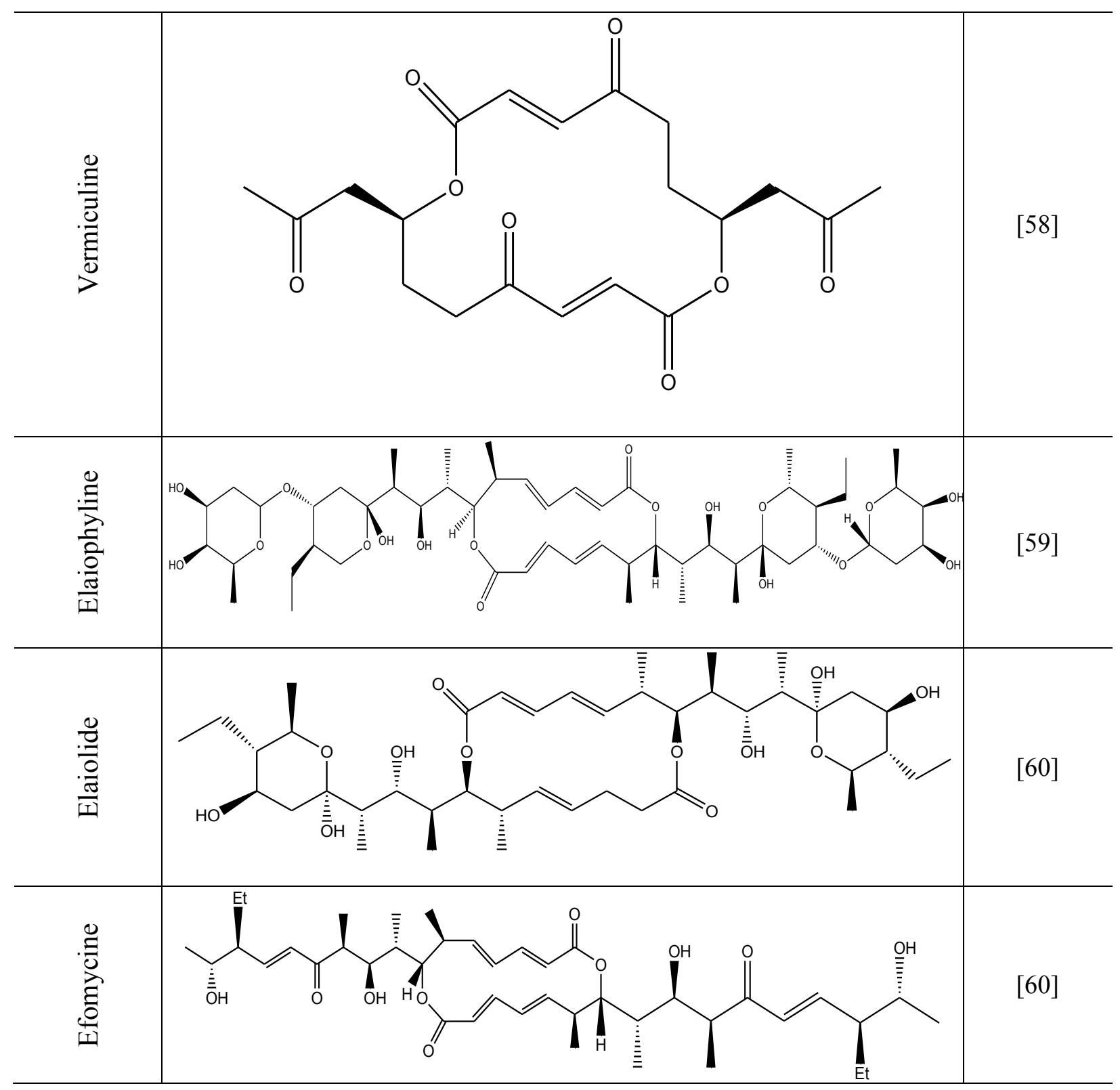

A quantitative characterization based on computed physicochemical property profiles such as Polarizability [29], Partition Coefficient (log P) [30-33], Hydration Energy [34-36], Molecular Volume [37], Molecular Surface and Molecular Mass [38] has been conducted. The physicochemical parameters used in the study are described below.

\section{Molecular Refractivity (MR)}

It is the measures of volume occupied by a group of atoms or atoms and is a measure of the susceptibility of the molecule to become polarized. It is a measure of overall bulkiness and is related to London dispersion forces using $\mathrm{MR}=4 \pi \mathrm{N} \alpha / 3$, where $\mathrm{N}$ is Avogadro number and $\alpha$ is the polarizability of the molecule. It gives no information about shape [39]. 


\section{Molecular weight (MW)}

Molecular weight descriptor has been used as a descriptor in systems such as transport studies where diffusion is the mode of operation. It is an important variable in QSAR studies pertaining to cross resistance of various drugs in multi-drug resistant cell lines [40].

\section{Octanol/water partition Log p:}

Coefficient are widely used to make estimates for membrane penetration and permeability, including gastrointestinal absorption [41,42], blood-brain barrier (BBB) crossing [43,44], and correlations to pharmacokinetic properties [45].

Hansch and Leo reasoned that highly lipophilic molecules will partition into the lipid interior of membranes and will be retained there [46].

LogP values between 0 and 3 , constitutes an optimal window for passive drug absorption. A $\log \mathrm{P}$ value below 0 means that the compound is hydrophilic, and hence it will have a good solubility but it may have poor permeability. Whereas, a $\log \mathrm{P}$ value far higher than 3 means that the compound is highly lipophilic, hence, tends to favor absorption, and renders the compounds more susceptible to metabolism and: or biliary clearance. The influence of lipophilicity on the metabolic clearance of drugs is attributed mainly to the increased affinity of drugs for the enzymes [47].

\section{Molecular volume}

Determines transport characteristics of molecules, such as intestinal absorption or blood-brain barrier penetration. Volume is therefore often used in QSAR studies to model molecular properties and biological activity [48].

\section{Molecular polarizability}

Molecular polarizability of a molecule characterizes the capability of its electronic system to be distorted by the external field, and it plays an important role in modeling many molecular properties and biological activities [49].

\section{The hydration Energy}

Hydration energy is the physicochemical property that calculated for each molecule is a key factor determining the stability of different molecular conformations [48].

\section{Solvent-accessible surface}

Solvent-accessible surface bounded molecular volume and van der Waals-surfacebounded molecular volume calculations are based on a grid method derived by Bodor et al. [50], using the atomic radii of Gavezotti [51].

\section{6. Structural Comparison of the 16-membered Macrodiolides}

Based on our conclusions on the effect of substitution on Macrodiolides molecules, we chose a series of Macrodiolides derivatives; some of them have a biological activity [52-60]. Initially, we performed a structural comparison of this series Figure 4. We used molecular mechanics with MM+ force-field and PM3 method to calculate the stable conformations of this series. These molecules have a weak conformational flexibility, with regard to the other macrocycles of macrolide type [61-67]. 


\section{7. Structure-activity Relationships of 16-membered Macrodiolides}

Lipophilicity is a property that has a major effect on solubility, absorption, distribution, metabolism, and excretion properties as well as pharmacological activity. Lipophilicity has been studied and applied as an important drug property for decades. It can be quickly measured or calculated. Lipophilicity has been correlated to many other properties, such as bioavailability, storage in tissues, permeability, and volume of distribution, toxicity, plasma protein binding and enzyme receptor binding $[68,69]$.

Polarizability values are generally proportional to the values of surfaces and of volumes, the decreasing order of polarizability for these studied Macrodiolides is: l'elaiophyline, clavosolide, elaiolide, efomycine, pamamycine 621, pamamycine 607, amphidinolide, LC28, vermiculine, pyrenophorol and pyrenophorine, Table 9. The order of polarizability is approximately the same one for volume and surface. This also is explained by the relation between polarizability and volume, for the relativity non polar molecules. They are directly linked, for the centers of gravity of negative and positive charges in the absence of external fields to coincide, and the dipole moment of the molecule is zero.

The polarizability of a molecule depends only on its volume, which means that the thermal agitation of non-polar molecules does not have any influence on the appearance of dipole moments in these molecules.

On the other hand, for the polar molecules, the polarizability of the molecule does not depend solely on volume but also depends on other factors such as the temperature because of the presence of the permanent dipole [70].

Surface and distribution volume of these molecules are definitely higher than those of more polar molecules like the lipopeptides or beta-lactams. For example, Deleu et al. used Tammo software on the surfactins C13, C14 and C15 having cores similar to the macrolides [71]. They found that their surfaces vary from 129 to $157 \AA 2$ [72], contrarily for these macrodiolides derivatives, surfaces vary from 493.94 to $1142.89 \AA^{2}$. These macrodiolides Derivatives has a great variation of distribution volume, in particular clavosolide and elaiophyline which have respective volumes: 2254.00 and $2466.14 \AA^{3}$ Table 9 .

The most important hydration energy in the absolute value is that of the elaiophyline $(16.64 \mathrm{kcal} / \mathrm{mol})$ and the weakest is that of amphidinolide $\mathrm{X}(01.00 \mathrm{kcal} / \mathrm{mol})$ Table 9. Indeed, in the biological environments the polar molecules are surrounded by water molecules.

They are established hydrogen bonds between a water molecule and these molecules. The donor sites of the proton interact with the oxygen atom of water and the acceptor sites of the proton interact with the hydrogen atom. The first corresponds to the complex with the strongest hydrogen bond. These hydrated molecules are dehydrated at least partially before and at the time of their interaction. These interactions of weak energy, which we observe in particular between messengers and receivers, are generally reversible [73].

The elaiophylin has eight proton donor sites $(8 \mathrm{OH}$ on two alkyl groups) and two proton acceptor sites $(2 \mathrm{C}=\mathrm{O}$ on the principal cycle). On the contrary, amphidinolide $\mathrm{X}$ has only three acceptor sites $[3 \mathrm{C}=\mathrm{O}(2$ on the principal cycle and 1 on the alkyl group)] and it does not have proton donor sites. This property supports the first compound, not only by fixing the receiver, but also activates it. It is thus about an agonist. It has as a consequence a better distribution in fabrics. All $(\log \mathrm{P})$ of studied molecules have optimal values. For good oral bioavailability, the $\log \mathrm{P}$ must be greater than zero and less than $3(0<\log \mathrm{P}<3)$. For $\log$ $\mathrm{P}$ too high, the drug has low solubility and a $\log \mathrm{P}$ too low; the drug has difficulty penetrating the lipid membranes [74]. Pyrenophorol presents the low coefficient of division (1.55) and comes after clavosolide A (1.88). 
These molecules possess a good solubility. When the coefficient of division is rather low, it has as a consequence a better gastric tolerance.

Compounds Efomycine and elaiophyline which have, respectively, higher values 8.14 and 7.86; these molecules are the most absorbent products and have important capacities to be dependent on plasmatic proteins.

Table 9. QSAR proprieties for 16-membered macrodiolides.

\begin{tabular}{|c|c|c|c|c|c|c|}
\hline Macrodiolides & $\begin{array}{c}\text { Volume } \\
\text { Moléculaire } \\
\left(\AA^{3}\right)\end{array}$ & $\begin{array}{c}\text { Surface } \\
\text { Moléculaire } \\
\left(\AA^{2}\right)\end{array}$ & $\begin{array}{l}\text { Masse } \\
\text { Moléculaire } \\
\text { (uma) }\end{array}$ & $\log P$ & $\begin{array}{c}\text { Énergie } \\
\text { d'hydratation } \\
\text { (Kcal/mol) }\end{array}$ & $\begin{array}{c}\text { Polarisabilité } \\
\qquad\left(\AA^{3^{3}}\right)\end{array}$ \\
\hline Pamamycine 607 & 1712.50 & 861.64 & 607.87 & 5.36 & 4.00 & 66.61 \\
\hline Pamamycine 621 & 1714.24 & 843.68 & 621.90 & 5.86 & 3.80 & 68.48 \\
\hline LC-28 & 1101.66 & 584.32 & 396.52 & 3.11 & 1.42 & 41.54 \\
\hline Clavosolide & 2254.00 & 1140.89 & 857.05 & 1.88 & -2.11 & 85.19 \\
\hline Amphidinolide-x & 1304.44 & 708.29 & 448.60 & 4.25 & 1.00 & 48.72 \\
\hline Pyrenophorol & 865.49 & 493.24 & 312.36 & 1.55 & -2.84 & 31.70 \\
\hline Pyrenophorine & 858.42 & 496.38 & 308.33 & 2.35 & -3.60 & 30.59 \\
\hline Vermiculine & 1070.75 & 608.34 & 392.41 & 2.21 & -1.42 & 38.11 \\
\hline Elaiophyline & 2466.14 & 1125.10 & 1026.29 & 7.86 & -16.64 & 105.69 \\
\hline Elaiolide & 1999.44 & 955.18 & 796.03 & 7.70 & -9.39 & 83.86 \\
\hline Efomycine & 2109.76 & 1142.89 & 728.96 & 8.14 & -9.46 & 80.08 \\
\hline
\end{tabular}

\section{8. Drug likeness calculation on the basis of Lipinski rule of five}

Drug-likeness appears as a promising paradigm to encode the balance among the molecular properties of a compound that influences its pharmacodynamics and pharmacokinetics and ultimately optimizes their absorption, distribution, metabolism and excretion (ADME) in human body like a drug [75,76]. The empirical conditions to satisfy Lipinski's rule and manifest a good oral bioavailability involve a balance between the aqueous solubility of a compound and its ability to diffuse passively through the different biological barriers.

These parameters allow to ascertaining oral absorption or membrane permeability that occurs when the evaluated molecule follows Lipinski's rule of five, evaluated molecule follows Lipinski's rule of five, molecular weight (MW) $\leq 500 \mathrm{Da}$, an octanol-water partition coefficient $\log \mathrm{P} \leq 5, \mathrm{H}$-bond donors, nitrogen or oxygen atoms with one or more hydrogen atoms $(\mathrm{HBD}) \leq 5$ and $\mathrm{H}$-bond acceptors, nitrogen or oxygen atoms $(\mathrm{HBA}) \leq 10$.

The above mentioned parameters were calculated for 1-11 and the results were presented in Tables 10. From the data obtained, it was observed that derivatives 3, 5, 6, 7 and 8 were found to obey the Lipinski rule, suggesting that these compounds theoretically would not have problems with oral bioavailability, whereas compounds $1,2,4,9,10$ and 11 were 
found doesn't obey the Lipinski rule, suggesting that these compounds theoretically would have problems with oral bioavailability.

There is much evidence that despite having molecular masses that are above 'rule of 5'compliant small molecules [77], macrocycles can demonstrate drug like physicochemical and pharmacokinetic properties such as good solubility, lipophilicity, metabolic stability and bioavailability.

Table 10. Lipinski's rule of five for drug likeliness of 16-membered macrodiolides.

\begin{tabular}{cccccc}
\hline Compound & MW (Da) & logP & HBD & HBA & $\begin{array}{c}\text { No. of violations of } \\
\text { Lipinski rule }\end{array}$ \\
\hline 1 & 607.87 & 5.36 & 0 & 6 & 2 \\
2 & 621.90 & 5.86 & 0 & 8 & 0 \\
3 & 396.52 & 3.11 & 0 & 6 & 2 \\
4 & 857.05 & 1.88 & 0 & 16 & 0 \\
5 & 448.60 & 4.25 & 0 & 6 & 0 \\
6 & 312.36 & 1.55 & 0 & 6 & 0 \\
7 & 308.33 & 2.35 & 2 & 6 & 0 \\
8 & 392.41 & 2.21 & 0 & 8 & 4 \\
9 & 1026.29 & 7.86 & 8 & 18 & 2 \\
10 & 796.03 & 7.70 & 6 & 12 & 4 \\
\hline 11 & 728.96 & 8.14 & 4 & & 10 \\
\hline
\end{tabular}

\section{CONCLUSION}

The present work studied the molecular proprieties of macrodiolide. The PM3, and ab initio method can be used quite satisfactorily in predicting the chemical reactivity of the molecules and the effect of substitution of either donor or acceptor electron. The 4,12dimethylmacrodiolide is predicted to be the most reactive with least HOMO-LUMO energy gap (14.5242) of all macrodiolide systems substituted by di-methyl, and in the substituted dibromine group category, the 2,10-di-bromine macrodiolide has smaller HOMO-LUMO energy gap (13.5761).

The compound efomycine present the higher coefficient of division. This lipophilic compound penetrates in various membranes, including cellular membranes as well as tissues with high lipoid content, to arrive at the receptor site. The compounds LC-28, Amphidinolide$\mathrm{x}$, Pyrenophorol, Pyrenophorine and Vermiculine were found to obey the Lipinski rule, suggesting that these compounds theoretically would not have problems with oral bioavailability, whereas others compounds were found doesn't obey the Lipinski rule, suggesting that these compounds theoretically would have problems with oral bioavailability. 


\section{References}

[1] E.M. Driggers, S.P. Hale, J. Lee, N.K. Terrett, Nat. Rev. Drug Discov. 7(2008) 608-624.

[2] J. Mallinson, I. Collins, Fut. Med. Chem. 4 (2012) 1409-1438.

[3] E. J. Kang, E. Lee, Chem. Rev. 105 (2005) 4348-4378.

[4] S. Muthusamy, M. Sivaguru, Tetrahedron. Lett 54 (2013) 6810-6813.

[5] (a) P. Magiatis, D. Spanakis, S. Mitaku, E. Tsitsa, A. Mentis, C.J. Harvala, Nat. Prod. 64 (2001)1093-1094; (b) Y. Minami, K. Yoshida, R. Azuma, M. Nishii, J. Inagaki, F. Nohara. Tetrahedron. Lett. 33 (1992) 7373-7376; (c) T. Ishida, Y. In, M. Nishii, Y. Minami, Chem. Lett. (1994) 1321-1322 ; (d) C. Christner, G. Kullertz, G. Fischer, M. Zerlin, S. Grabley, R. Thiericke, A. Taddei, A.J. Zeeck, Antibiot. 51 (1998) 368-371.

[6] (a) E. M. Driggers, S. P. Hale, J. Lee, N. K. Terrett, Nat. Rev. Drug Disc. 7 (2007) 608624; (b) E. Marsault, M. L. Peterson, J. Med. Chem. 54 (2011) 1961-2004.

[7] D. F. Veber, S. R. Johnson, H.-Y. Cheng, B. R. Smith, K. W. Ward, K. D. Kopple, J. Med. Chem. 45 (2002) 2615-2623.

[8] S. Omura, Macrolide Antibiotics: Chemistry, Biology and Practice; Academic: New York, 1984, 538.

[9] J. S. Yadav, U. V. Subba Reddy, B. V. Subba Reddy, Tetrahedron. Letters 50 (2009) 5984-5986.

[10] J. G. Topliss, Perspect. Drug. Discov. Des. 1 (1993) 253.

[11] W. Zhigao, W. Fangqiang, Su. Changhua, Z. Yongling, J. Comput. Theor. Nanosci. 10 (2013) 2323-2327.

[12] A. Eghdami, M. Monajjemi, Quantum Matter 2 (2013) 324-331.

[13] Y. Chen, Di. Xu, M.Yang, J. Comput. Theor. Nanosci. 10 (2013) 2916-2919.

[14] B. Wu, X. Kong, Z. Cao, Y. Pan, Y. Ren, Y. Li, Q. Yang, and F. Lv, J. Comput. Theor. Nanosci. 10(2013) 2403-2410.

[15] M. Ciobanu, L. Preda, D. Savastru, R. Savastru, E. M. Carstea, Quantum. Matter. 2 (2013) 60.

[16] S. Anurag, J. Srashti, A. K. Nagawat, Quantum. Matter. 2 2013) 469-473.

[17] A. Srivastava, N. Saraf, A. K. Nagawat, Quantum. Matter. 2 (2013) 401-407.

[18] A. Srivastava, N. Jain, A. K. Nagawat, Quantum. Matter. 2 (2013) 307-313.

[19] M. Joydeep, Ch. Raja, S. Saikat, V. Anjay, De. Biplab, T. K. Ravi, Der. Pharma. Chemica 1(2) (2009) 188-198.

[20] HyperChem (Molecular Modeling System) Hypercube, Inc. USA, (2007).

[21] J. J. P. Stewart, J. Comput. Chem. 10 (1989) 221-264.

[22] S. Belaidi, M. Laabassi, R. Gree, A. Botrel. Scientific Study \& Research 4 (2003) 27-38.

[23] S. Belaidi, N. Melkemi, Asian Journal of Chemistry 25 (2013) 4527-4531

[24] I. Fleming, Frontier Orbitals and Organic Chemical Reactions (John Wiley and Sons, NewYork, 1976, 5-27. 
[25] J. S. Murray, K. Sen, Molecular Electrostatic Potentials, Concepts and Applications Elsevier, Amsterdam, 1996.

[26] I. Alkorta, J. J. Perez, Int. J. Quant. Chem. 57 (1996) 123.

[27] E. Scrocco, J. Tomasi, Adv. Quantum Chem. 11 (1978) 115.

[28] F. J. Luque, M. Orozco, P. K. Bhadane, S. R. Gadre, J. Phys. Chem. 97 (1993) 9380.

[27] J. Sponer, P. Hobza, Int. J. Quant. Chem. 57 (1996) 959.

[28] G. L. Miessler., D. A. Tarr. Inorganic. Chemistry, 2nd ed, Prentice-Hall Upper Saddle River, NJ, USA. (1999).

[29] R. P. Verma, A. Kurup, C. Hansch, Bioorganic \& Medicinal Chemistry 13 (2005) 237255.

[30] W. J. Lyman, Rosenblatt, Eds.; American Chemical Society: Washington. DC., 1-1-1$51,(1990)$.

[31] A. Sabljic, H. Guesten, J. Hermens, A. Opperhuizen, Environmental Science \& Technology 27 (1993) 1394-1402.

[32] C. Hansch, A. J. Leo, Wiley: New York, (1979).

[33] T. Suzuki, Y. Kudo, Journal of Computer-Aided Molecular Design 4 (1990) 155-198.

[34] A. Khalafi-Nezhad, M. N. Soltani Rad, H. Mohabatkar, Z. Asrari, B. Hemmateenejad, Bioorg. Med. Chem. 13 (2005) 1931-1938.

[35] H. Liu, Y.-M. Du, J. F. Kennedy, Carbohydrate. Polymers. 68 (2007) 598-600.

[36] G. E. Chudinov, D. V. Napolov, M. V. Basilevsky, Chemical. Physics 160 (1992) 4154.

[37] P. D. Leeson, A. M. Davis, J. Med. Chem. 47 (2004) 6338-6348.

[38] M. Yadav, Bioinformation 7 (2011) 388-392.

[39] L. K. Ojha, Ajay M. Chaturvedi, A. Bhardwaj, M. Thakur,A. Thakur, IJPAC 3(4) (2013) 417-427.

[40] M. Yadav, Bioinformation .,7(8) (2011) 388-392.

[41] S. Winiwarter, N. M. Bonham, F. Ax, A. Hallberg, H. Lennerna"s, A.Karlen, J. Med. Chem. 41 (1998) 4939-4949.

[42] P. Artursson, J. Karlsson, Biochem. Biophys. Res. Commun. 175 (1991) 880-885.

[43] R. C. Young, R. C. Mitchell, Th. H. Brown, C. R. Ganellin, R. Griffiths, M. Jones, K. K. Rana, D. Saunders, I. R. Smith, N. E.Sore, T. J. Wilks, J. Med. Chem. 31 (1988) 656671.

[44] H. Van de Waterbeemd, G. Camenisch, G. Folkers, J. R. Chre'tien, O. A. Raevsky, J. Drug. Target. 2 (1998) 151-165.

[45] D. A. Smith, B. C. Jones, D. K. Walker, Med. Res. Rev. 16 (1996) 243-266.

[46] H. Pajouhesh, G. R. Lenz, Neurotherapeutics 2 (2005) 541.

[47] R. Panchagnula, N. S. Thomas, Int. J. Pharm. 201 (2000) 131-150. 
[48] P. Lalitha, S. Sivakamasundari, Orient. J. Chem. 26(1) (2010) 135-141

[49] J. Wang, X.Q. Xie, T. Hou, X. Xu, Fast J. Phys. Chem. A. 24;111(20) (2007) 44434448 .

[50] S. Lanners, H. Norouzi-Arasi, Xavier J. Salom-Roig, G. Hanquet, A. Chemie 119 (2007) 7216-7219.

[51] A. Gavezzotti, J. Am. Chem. Soc. 105 (1983) 5220-5225.

[52] O. Germay, N. Kumar, Eric. J. Thomas, Tetrahedron. Lett, 42, 30, 23 (2001) 49694974.

[53] H. R. Jois, A. Sarkar, S. Gurusiddaiah, Antimicrob. Agents Chemother 30(3) (1986) 458.

[54] T. K. Chakraborty, V. R. Reddy, A. Kumar, Tetrahedron. Lett, 47, 42 (2006) 74357438.

[55] O. Kattnig, E. Furstner, J. Am. Chem. Soc. 126 (2004) 15970-15971.

[56] S. Amigoni, Y. Le Floc'h, Tetrahedron: Asymmetry, 8, 16 (1997) 2827-2831.

[57] J. Gailliard, Synthese formelle de la pyrenophorine, Thèse de doctorat en Chimie; université de Rouen.(1990).

[58] A. Noda, S. Aoyagi, N. Machinaga, Ch. Kibayashi, Tetrahedron. Lett. 35, 44 (1994) 8237-8240.

[59] I. Paterson, J. Man. Tetrahedron. Lett, 38, 4 (1997) 695-698.

[60] R. Barth, J. Mulzer, Tetrahedron. 64, 21 (2008) 4718-4735.

[61] S. Belaidi, M. Omari , J. Soc. Alger. Chim. 10 (2000) 31-40,

[62] S. Belaidi, M. Omari et A. Dibi, J. Soc. Alger. Chim. 10(2) (2000) 221.

[63] S. Belaidi, A. Dibi, M. Omari, Turk. J. Chem. 26 (2002) 491-500.

[64] S. Belaidi, M. Omari, T. Lanez, A. Dibi, J. Soc. Alger. Chim. 14 (2004) 27-39

[65] S. Belaidi., T. Lanez, M. Omari, A. Botrel. Asian J. Chem. 17 (2005) 859-870.

[66] S. Belaidi, M. Laabassi, R. Gree, A. Botrel, Rev. Roum. Chim. 50 (2005) 759-765.

[67] S. Belaidi, D. Harkati, ISRN Organic Chemistry, (2011) 594242.

[68] E. H. Kerns, L. Di, Academic. Press, USA. (2008) 43-47.

[69] V. Pliska, B. Testa, H. van de Waterbeemd, R. Mannhold, H. Kubinyi, H. Timmerman, Lipophilicity in Drug Action and Toxicology, Wiley-VCH, Federal Republic of Germany (1996).

[70] B. Yavorski, A. Detlaf, Checklist of Physics. 1980, 376.

[71] TAMMO Theoretical Analysis of Molecular Membrane Organization, CRC Press, Boca Raton, Florida, USA (1995).

[72] Deleu M Synthesis of Surfactin Derivatives and Study Their Properties, Thesis Ph.D, FUSAGX, Belgique (2000). 
[73] L. B. Kier, Molecular Orbital Theory in Drug Research, Academic Press. New York. NY. USA (1981).

[74] E. H. Kerns, L. Di, Drug-like Properties: Concepts, Structure Design and Methods: from ADME to Toxicity Optimization, Academic Press, USA, (2008) 43-47.

[75] Ch. A. Lipinski, Franco Lombardo, B. W. Dominy, P. J. Feeney, Adv. Drug Deliv. Rev. 64 (2012) 4-17.

[76] G. Vistoli, A. Pedretti, B. Testa, Drug. Discov. Today. 13(7-8) (2008) 285-294.

[77] C. A. Lipinski, F. Lombardo, B. Dominy, W. P. J. Feeney. Adv. Drug. Deliv. Rev. 23 (1997) 3-25. 